\title{
IDENTIFIKASI DAN STRATEGI PENGEMBANGAN HIJAUAN MAKANAN TERNAK DI PERKEBUNAN KELAPA SAWIT
}

\author{
LAODE MUH MUNADI
}

\author{
Pascasarjana Ilmu Pertanian Universitas Halu Oleo \\ Kendari, Sulawesi Tenggara \\ Email:1mmunadi@gmail
}

\section{BAB I \\ PENDAHULUAN}

\begin{abstract}
Pengelolaan perkebunan kelapa sawit termasuk padat modal, untuk aktivitas perawatan tanaman, pengendalian gulma, biaya pengadaan pupuk organik dan anorganik. Permasalahan di atas dapat diminimalisir dengan cara menekan biaya untuk pengendalian gulma dan pengadaan pupuk organik. Integrasi sawit-sapi selain menekan biaya herbisida juga menjadikan pengendalian gulma secara biologi, sehingga lebih ramah lingkungan. Jenis tumbuhan di bawah perkebunan kelapa sawit, bervariasi antara perkebunan satu dengan yang lain. Umur kelapa sawit kemungkinan akan mempengaruhi keragaman tumbuhan yang di bawah perkebunan kelapa sawit. Jenis tumbuhan di bawah tanaman kelapa sawit antara lain rumput-rumputan, tumbuhan berdaun sempit, tumbuhan berdaun lebar yang dikelompokkan dalam gulma. Namun, ada juga tumbuhan leguminosa. Jenis leguminosa ini juga dibudidayakan di bawah tanaman kelapa sawit saat tanaman masih muda dan berfungsi sebagai penutup tanah, maka penutup tanah di perkebunan berfungsi untuk menjaga kelembaban tanah dan menjaga kesuburan tanah. Istilah lain gulma adalah tumbuhan pengganggu, yang mengandung pengertian semua jenis tumbuhan yang menghambat dari berbagai jenis tanaman yang diusahakan atau dibudidayakan baik oleh petani maupun usaha pertanian swasta. Gulma tersebut perlu diberantas, namun gulma dapat menjadi tanaman
\end{abstract} yang sangat dibutuhkan oleh ternak sebagai sumber hijauan.

Hijauan merupakan sumber pakan utama untuk ternak ruminansia, sehingga untuk meningkatkan produksi ternak ruminansia harus diikuti oleh peningkatan penyediaan hijauan yang cukup baik dalam kuantitas maupun kualitas. Beberapa faktor yang menghambat penyediaan hijauan, yakni terjadinya perubahan fungsi lahan yang sebelumnya sebagai sumber tumbuhnya hijauan pakan menjadi lahan pemukiman, lahan untuk tanaman pangan, dan tanaman industri.

Hijauan pakan ternak terutama jenis rumput-rumputan dan limbah pertanian merupakan bahan pakan yang mengandung serat kasar atau bahan yang tak tercerna relatif tinggi. Namun ternak ruminansia membutuhkan sejumlah serat kasar tersebut di dalam ransumnya agar proses pencernaan berjalan secara lancar dan optimal. Sumber utama serat kasar itu sendiri adalah rumput-rumputan, baik jenis rumput unggul maupun rumput alam sedangkan jenis leguminosa merupakan pakan sumber protein. Ketersediaan hijauan pakan ternak harus selalu ada mengingat kebutuhan ternak ruminansia terhadap hijauan dalam bentuk segar adalah berkisar 10-15\% dari bobot badan hidup. Disamping itu, kualitas hijauan pakan ternak juga perlu diperhatikan terutama kandungan nutrien nya harus dapat memenuhi kebutuhan hidup pokok dan produksi pada ternak ruminansia ketika mengkonsumsi pakan hijauan.

Keragaman hijauan pakan ternak pada kawasan perkebunan kelapa sawit merupakan salah satu langkah alternatif yang tepat dalam memanfaatkan sumberdaya hijauan yang didukung oleh luasnya kawasan perkebunan sebagai penunjang kawasan penyedia hijauan. 
Khususnya ternak yang masih menggantungkan pakan hijauan dari alam (rumput/leguminosa lokal) walaupun ketersediaan nya tidak kontinyu. Untuk mengetahui Kuantitas hijauan pada wilayah perkebunan kelapa sawit tersebut dapat dilakukan dengan analisis kerapatan vegetasi. Gulma yang ada di perkebunan sawit, dapat menjadi sumber hijauan pakan ternak, walaupun tidak semua tumbuhan disukai ternak. Sehingga penulis mencoba mengangkat topik makalah yang berjudul "Identifikasi dan Strategi Pengembangan Hijauan Makanan Ternak di Perkebunan Kelapa Sawit".

\section{BAB II \\ PEMBAHASAN}

\subsection{Ketersediaan HMT Pada Perkebunan Kelapa Sawit}

Berdasarkan hasil survei dan identifikasi terhadap jenis vegetasi yang terdapat pada perkebunan kelapa sawit, diperoleh beberapa tumbuhan yang biasa di kelompokkan ke dalam 10 (sepuluh) family tumbuhan dan digunakan 4 karakteristik morfologi dasar yang dapat digunakan untuk mengidentifikasi vegetasi yang ada yaitu akar, batang, daun dan bunga. Lebih jelasnya disajikan pada Tabel 1 .

Tabel 1. Spesies Tumbuhan Pada Perkebunan Kelapa Sawit

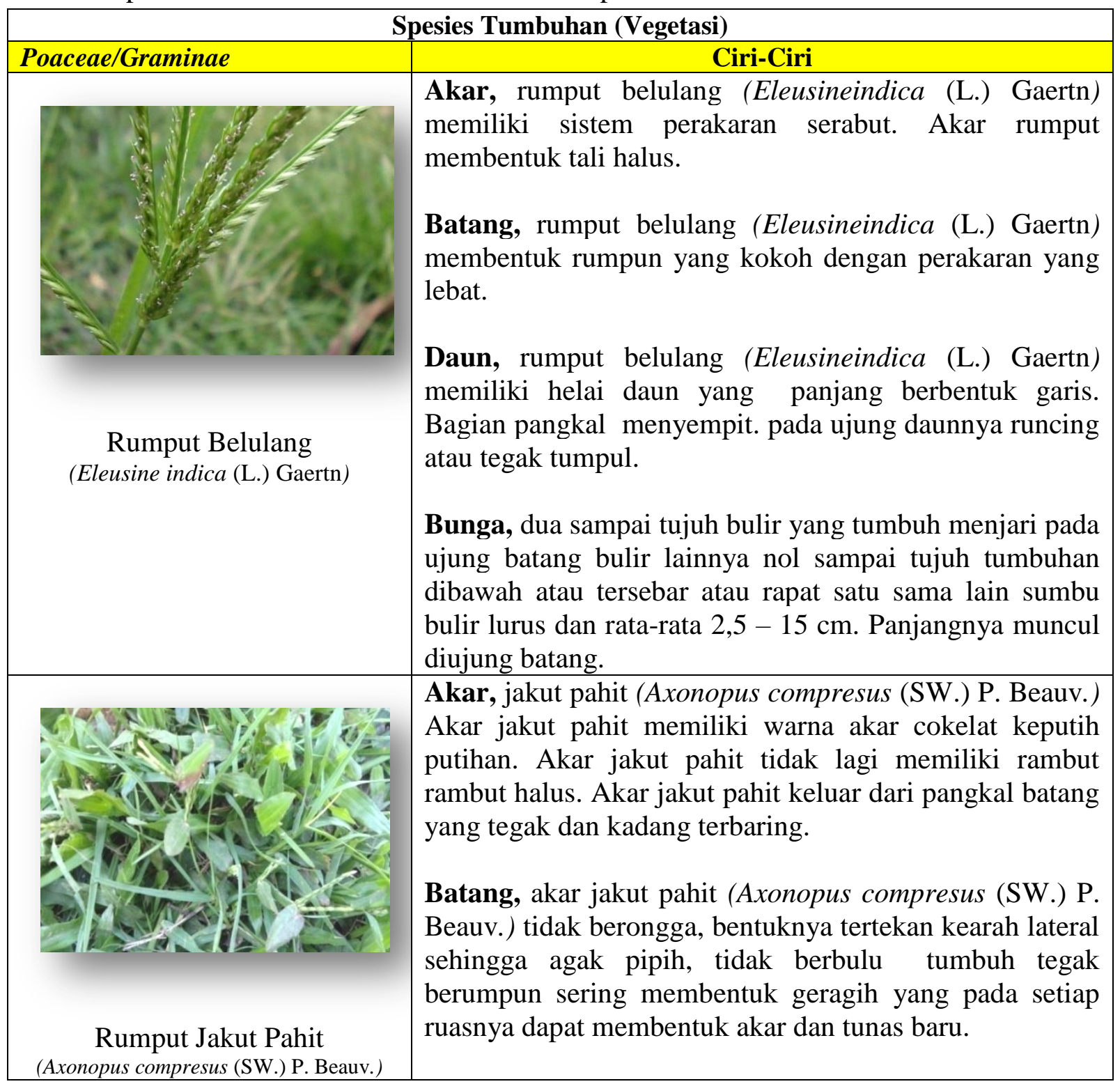




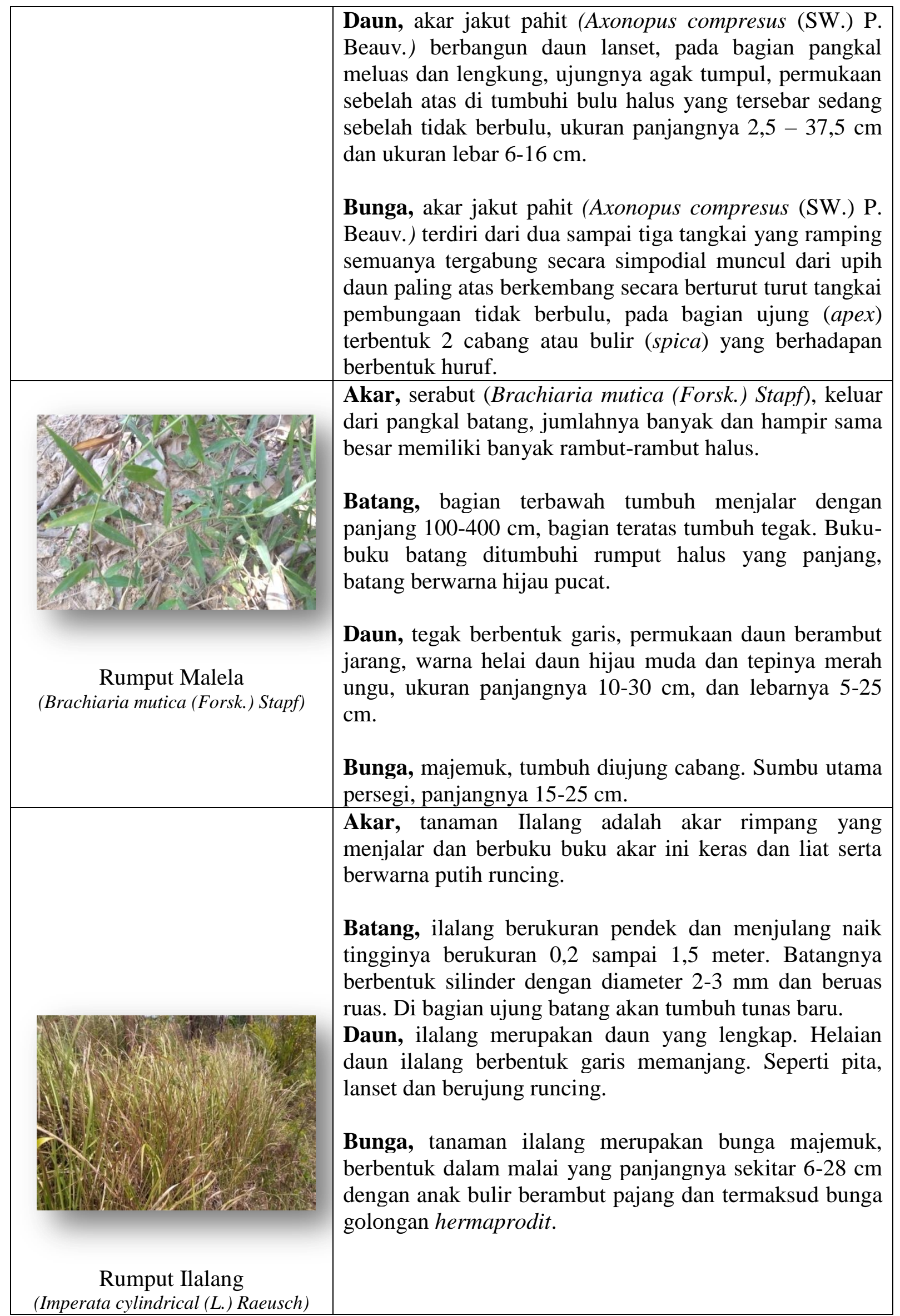




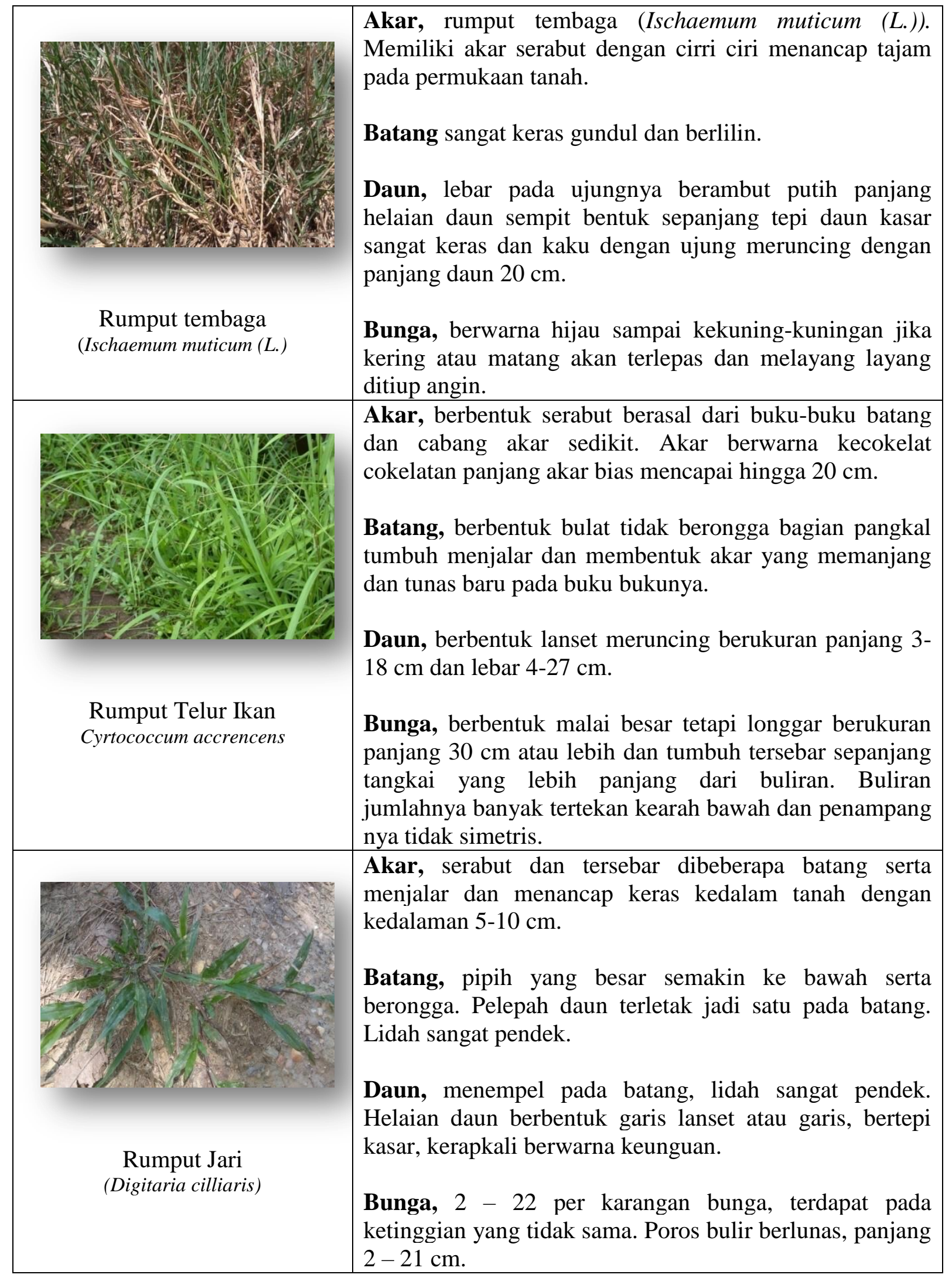




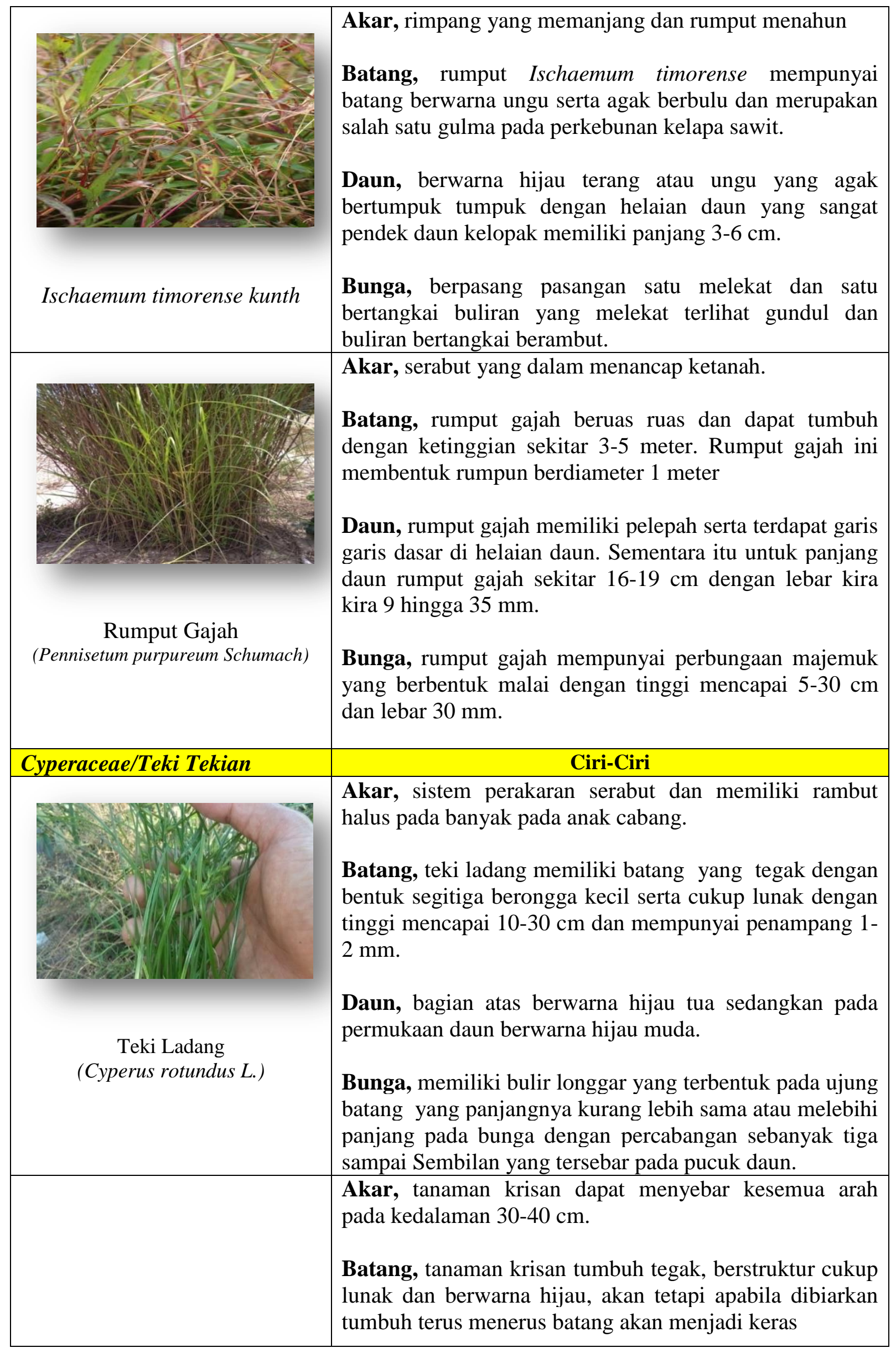




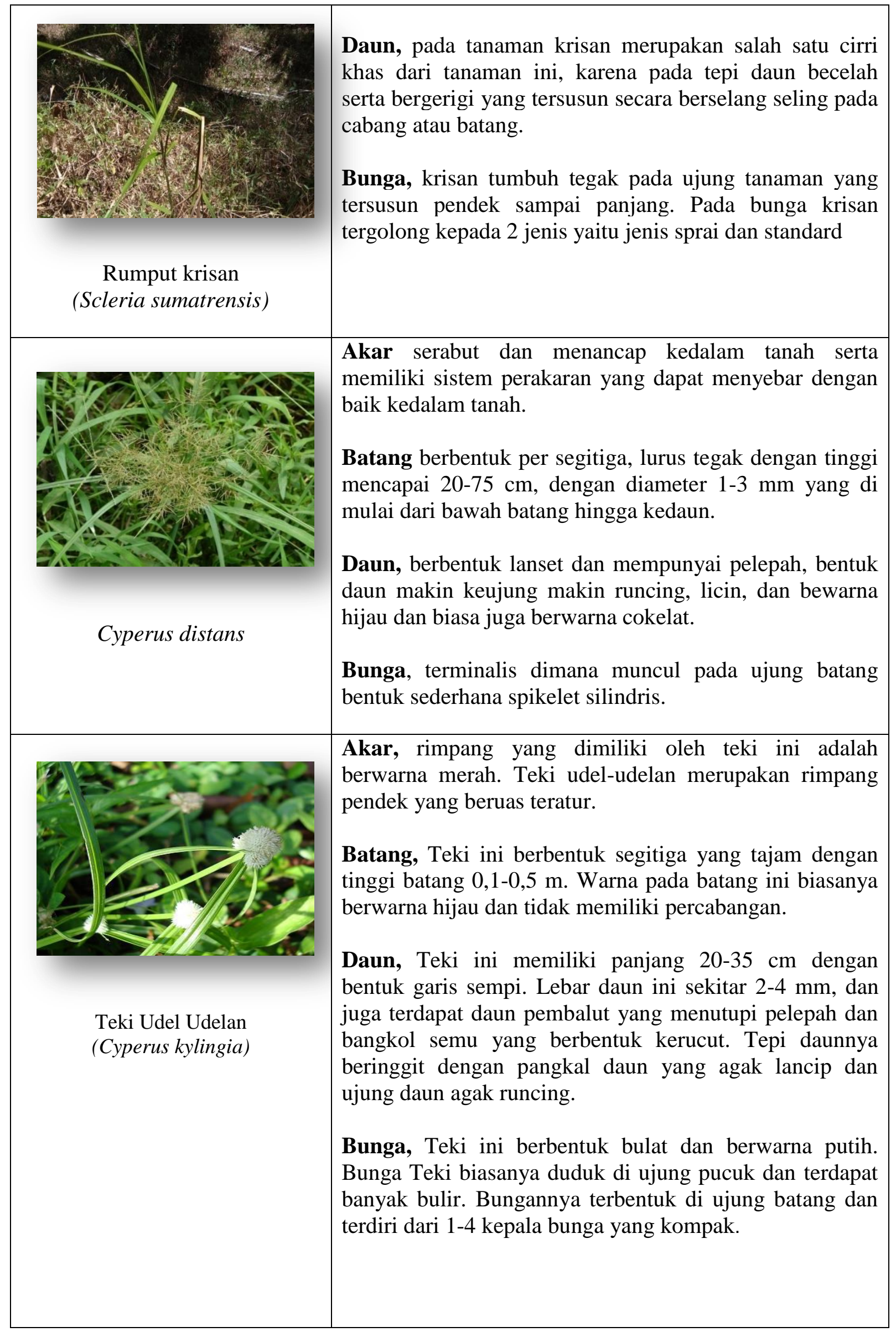




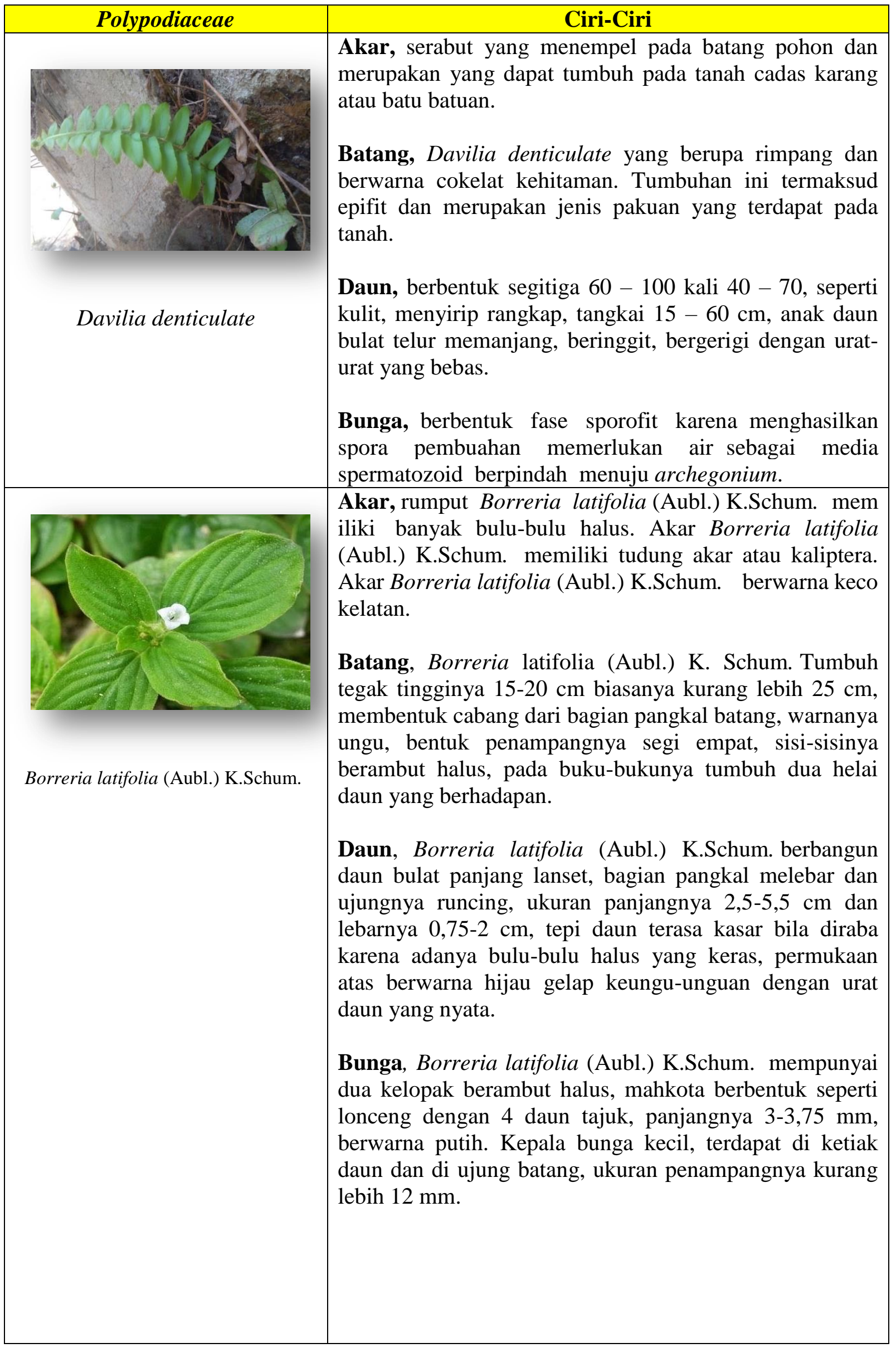




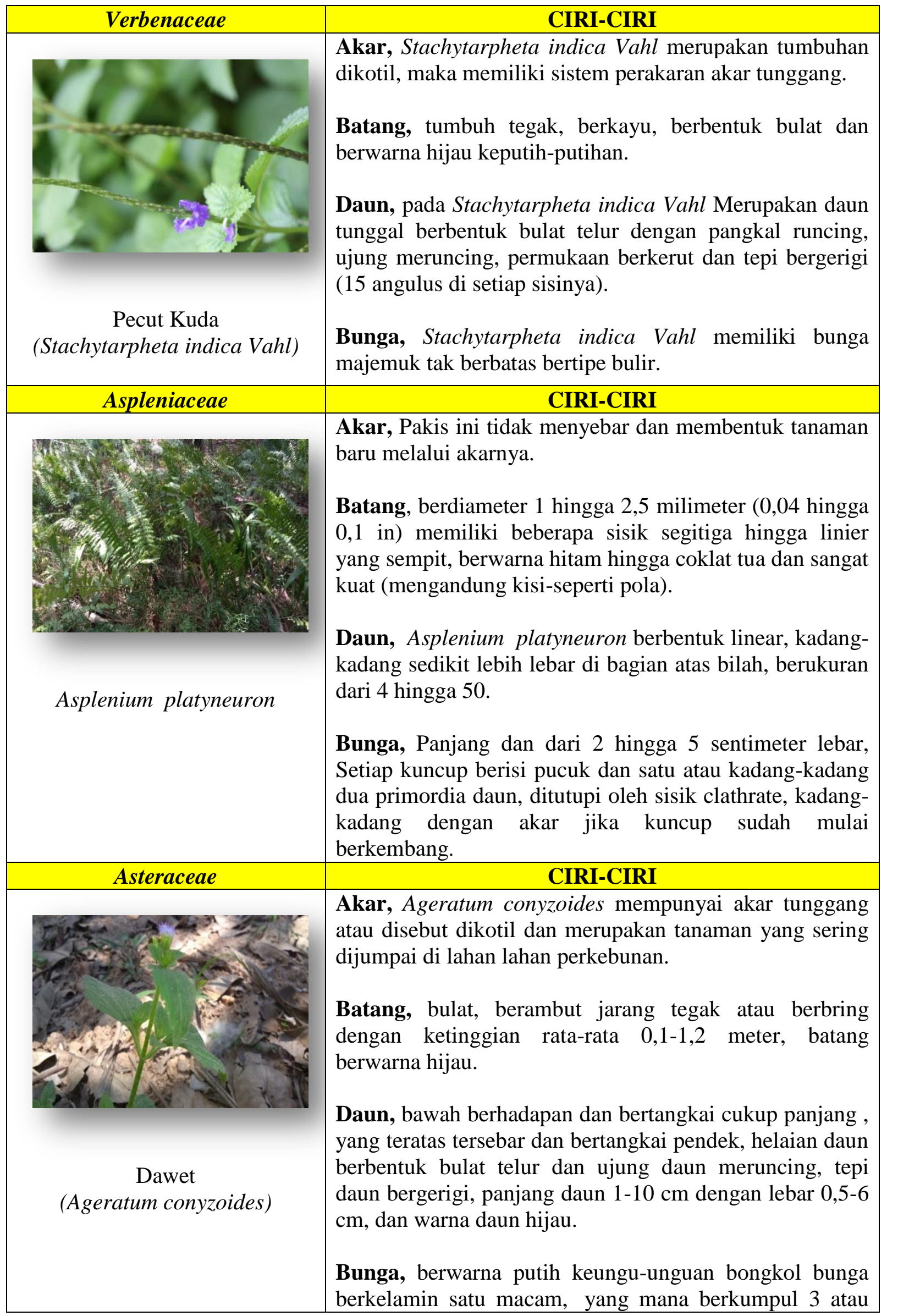




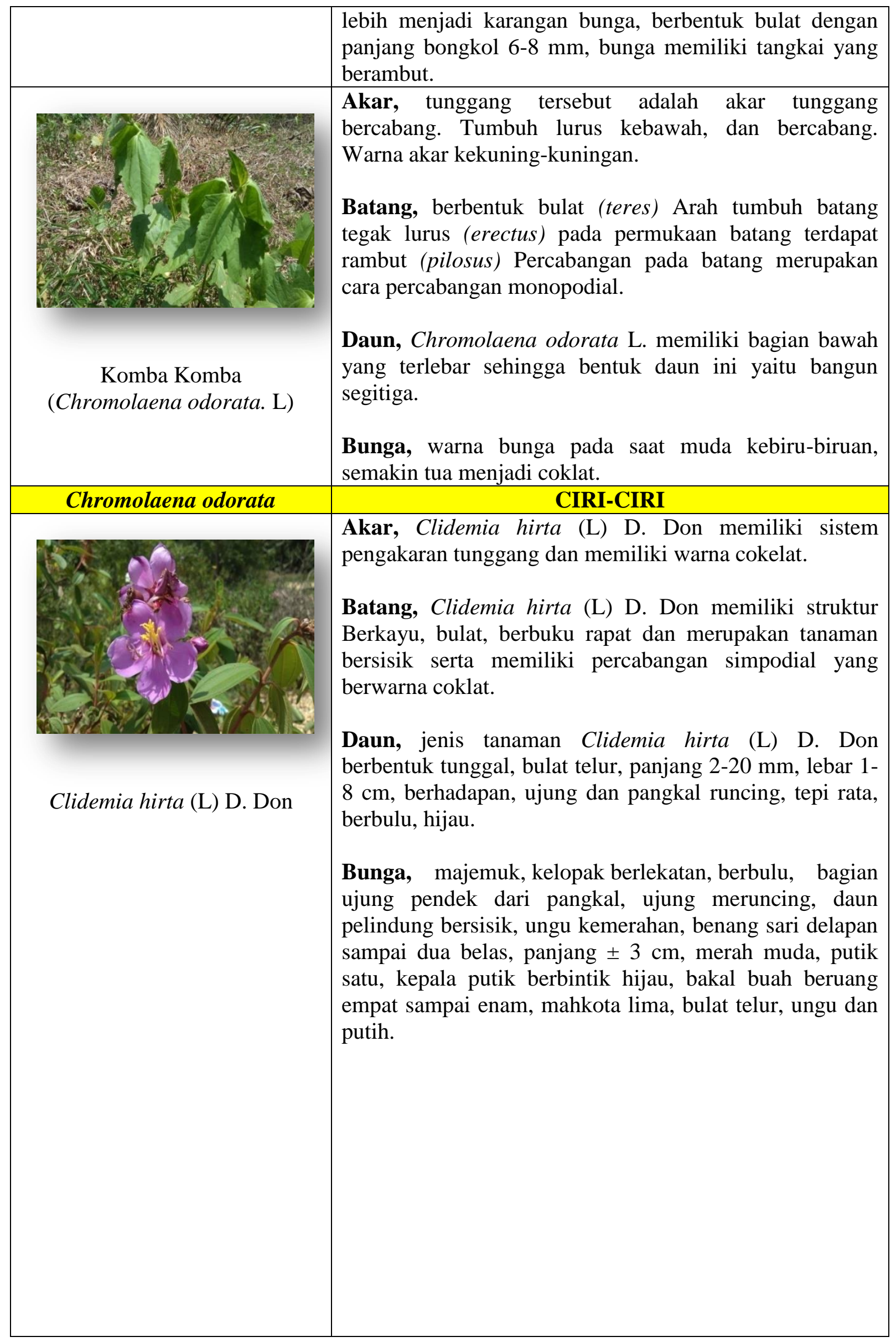




\begin{tabular}{|c|c|}
\hline & Ciri-Ciri \\
\hline$\frac{12}{2}$ & $\begin{array}{l}\text { Akar, tumbuhan putri malu berserabut, berwarna } \\
\text { kecoklatan, tumbuh menyebar di permukaan media tanah, } \\
\text { dan mencapai kedalaman } 30-60 \mathrm{~cm} \text { bahkan lebih. } \\
\text { Batang, tumbuhan putri malu berbentuk bulat, seluruh } \\
\text { batang di selimuti oleh duri yang menempel, dengan } \\
\text { panjang yang beragam tergantung dengan pertumbuhan } \\
\text { putri malu. } \\
\text { Daun, putri malu berupa daun majemuk yang menyirip } \\
\text { ganda dua sempurna. Jumlah anak daun sirip berkisar } 5- \\
26 \text { pasangan. } \\
\text { Bunga, tumbuhan putri malu berbentuk bulat, hampir } \\
\text { menyerupai bola dan tidak memiliki mahkota atau } \\
\text { kelopak bunga besar seperti bunga pada jenis tumbuhan } \\
\text { lainnya. }\end{array}$ \\
\hline & CIRI-CIRI \\
\hline noides & $\begin{array}{l}\text { Akar, Calopogonium mucunoides memiliki sistem } \\
\text { perakaran tunggang, berwarna putih kecoklatan, akar } \\
\text { akan kontak dengan tanah ketika bagian atas } \\
\text { batang menjadi kuat. } \\
\text { Batang, padat merona dengan rambut-rambut yang } \\
\text { tersebar dan berwarna hijau yang tersebar keseluruh } \\
\text { batang. } \\
\text { Daun, Calopogonium mucunoides berbentuk menjorong, } \\
\text { membundar telur atau mengetupat membundar telur } \\
\text { dengan ukuran } 1.5 \text { - } 4 \text { cm, bagian lateral menyerong, } \\
\text { kedua permukaan merona melekap atau gundul. } \\
\text { Bunga, tandan lampai, panjang hingga } 20 \mathrm{~cm} \text {, panjang } \\
\text { tangkai bunga 0-17 cm, meroma, bunga dalam fasikulum } \\
\text { berjumlah } 2-6 \text {, berwarna biru atau ungu. }\end{array}$ \\
\hline (Alysicarpus vaginalis (L.) DC) & $\begin{array}{l}\text { Akar, Alysicarpus vaginalis (L.) DC. Memiliki perakaran } \\
\text { serabut. } \\
\text { Batang, berdiri tegak setinggi } 6 \mathrm{~cm} \text {. Panjang batangnya } \\
10-100 \mathrm{~cm} \text {, bercabang dengan buku-bukunya yang dalam } \\
\text { kondisi lembab dapat tumbuh perakaran baru. } \\
\text { Daun, Alysicarpus vaginalis (L.) DC memiliki daun } \\
\text { tunggal sederhana berbentuk oval dan merupakan } \\
\text { tanaman merambat semusim atau tanaman tahunan } \\
\text { berumur pendek. } \\
\text { Bunga, per rangkaian bisa mencapai } 12 \text { kuntum. }\end{array}$ \\
\hline
\end{tabular}




\begin{tabular}{|c|c|}
\hline & $\begin{array}{l}\text { Penampang bunga hanya beberapa centimeter saja } \\
\text { panjangnya, berwarna merah atau ungu atau biru atau } \\
\text { kuning. Termasuk polong-polongan karena buah } \\
\text { kacangnya berada di atas tanah. }\end{array}$ \\
\hline & $\begin{array}{l}\text { Akar, Memiliki sistem perakaran tunggang dan berwarna } \\
\text { cokelat. }\end{array}$ \\
\hline & $\begin{array}{l}\text { Batang, Merupakan tanaman merambat dengan batang } \\
\text { cokelat berbulu agak keputih-putihan }\end{array}$ \\
\hline & $\begin{array}{l}\text { Daun, biasanya memiliki } 3-5 \text { anak daun bentuk daun } \\
\text { elips, lanset dan bulat telur. }\end{array}$ \\
\hline $\begin{array}{c}\text { Jakut Jeram } \\
\text { (Desmodium triflorum }(L\end{array}$ & $\begin{array}{l}\text { Bunga, daun berwarna ungu, merah muda, ungu atau } \\
\text { putih terletak pada ketiak atau didalam ujung perbungaan. }\end{array}$ \\
\hline
\end{tabular}

Sumber: Munadi, 2019

Berdasarkan Tabel 1 menunjukkan bahwa jenis vegetasi yang mendominasi daerah penelitian adalah dari famili poaceae/graminae dengan 9 jenis. Kemudian diikuti oleh jenis cyperaceae atau teki tekian dengan 4 jenis diantaranya teki ladang (cyperus rotundus), rumput krisan (scleria sumatransis), cyperus distans, teki udel-udelan (cyperus kylingia) dan untuk famili leguminaceae terdapat tiga jenis diantaranya colopogonium mucunoides, alysicapus vaginalis (L). DC dan daun mules (dismodium triflorum). Untuk kategori famili asteraceae terdapat dua jenis seperti dawet (ageratum conyzoides) dan komba komba (chromolaena odorata. L). Sementara itu, untuk famili polypodiaceae memiliki 1 jenis yaitu (davilia denticulate), rubiaceae (borreria latifolia (Aubl) K. Schum), verberiaceae pecut kuda (stachytarphita indica Vahl), aspleniaceae (asplenium platyneuron), cromolaena odorata (clidemia hirta (L) D. Don) dan famili mimosaceae dengan bahasa latin (mimosa pudica Linn) atau masyarakat menyebutnya dengan nama putri malu. Afrianti et al., (2014) menyatakan tingginya tingkat frekuensi dan frekuensi relatif gulma atau persaingan gulma tergantung pada curah hujan, varietas, kondisi tanah, kerapatan gulma, lamanya tanaman dan gulma bersaing, umur tanaman saat gulma mulai bersaing. Saleh et al., (2020) menyatakan bahwa secara fisik gulma bersaing dengan tumbuhan dalam hal pemanfaatan ruang, cahaya dan secara kimiawi dalam hal pemanfaatan air, nutrisi, gas-gas penting dalam proses alelopati.

Saleh et al., (2020) dengan judul penelitian Keragaman Gulma Pada Tanaman Kelapa Sawit (Elaies guineensis Jacq.) Belum Menghasilkan Dan Sudah Menghasilkan Di Kebun Rambutan PT. Perkebunan Nusantara III mengemukakan bahwa Keragaman gulma dari masing-masing area bervariasi, terdapat 29 spesies gulma dan 20 famili, namun, terdapat 5 spesies gulma yang ditemukan di semua area penelitian; O. nodusa, Poaceae; $C$. kyllingia, Cyperaceae; A. comressus, Poaceae; P. Niruri, Phyllanthaceae; A. spinous, Amaranthaceae. Gulma yang dominan di area yang belum menghasilkan adalah E. indica, Poaceae sedangkan di daerah menghasilkan adalah O. nodosa, Poaceae. Selanjutnya Suryana et al., (2019) dengan penelitian Identifikasi Spesies Tanaman Penutup Tanah pada Perkebunan Kelapa Sawit Menghasilkan mengemukakan bahwa Hasil analisis iklim mikro kelapa sawit umur 5 tahun menghasilkan di Jonggol intensitas cahaya sebesar 1094.7 lux dengan suhu $28.5^{\circ} \mathrm{C}$ dan kelembaban $68.76 \%$, sedangkan kelapa sawit umur 10 tahun menghasilkan di Cikabayan intensitas cahaya sebesar 997.8 lux dengan suhu $32.5^{\circ} \mathrm{C}$ dan kelembaban $87.25 \%$. Spesies 
Asystasia gangentica, Axonopus compressus, Borreria alata, dan Ottochloa nodosa merupakan vegetasi tumbuhan yang dominan pada dua ekosistem. Asystasia gangentica mampu tumbuh dan menutup tanah dengan optimum pada semua tingkat naungan, sedangkan Axonopus compressus, Borreria alata, dan Ottochloa nodosa dapat tumbuh dan menutup tanah dengan sempurna hanya pada naungan $0 \%$ serta $25 \%$ dan $50 \%$.

Trisna et al., (2018) dengan penelitian Tumbuhan Bawah Pada Perkebunan Kelapa Sawit Tua (Tm) Dan Sawit Muda (TI) Dengan Peremajaan Teknik Underplanting di PT. Bio Nusantara Teknologi mengungkapkan bahwa komposisi tumbuhan bawah pada TM ditemukan 20 jenis yang terdiri dari 5 jenis asli dan 15 jenis asing dan pada kebun TI ditemukan 20 jenis yang terdiri dari 8 jenis asli dan 12 jenis asing. Tingkat keragaman jenis tumbuhan bawah ( $\left.\mathrm{H}^{\prime}\right)$ tergolong rendah dengan besaran masing-masing pada TM sebesar 0,637 dan TI dengan nilai 1,94. Jenis yang mendominasi pada kedua kondisi kebun kelapa sawit adalah Axonopus compressus dengan INP 130,238\% (TM) dan 42,237\% (TI).

Kocu et al., (2017) dengan penelitian Produktivitas Sapi Bali di Lahan Pastura dan Perkebunan Kelapa Sawit di Kabupaten Keerom Provinsi Papua mengungkapkan bahwa Sapi bali yang dipelihara pada lahan pastura memiliki produktivitas yang lebih tinggi terutama bobot badan dan tinggi pinggul. Produktivitas yang lebih tinggi pada lahan pastura karena pemberian suplementasi tambahan rumput unggul yakni rumput gajah (Penisetum purpureum) dan Rumput Raja (King grass). Secara umum sapi bali yang dipelihara pada kedua areal yang berbeda memiliki produktivitas yang baik kareana daya dukung lahan tinggi dan populasi ternak masih rendah.

Gopar et al., (2015) dengan judul penelitian Potensi Covercrop Kebun Sawit Sebagai Sumber Pakan Hijauan Ternak Ruminansia Pada Musim Kemarau di Pelalawan, Riau. Mengungkapkan bahwa jumlah vegetasi/covercrop yang ada di kebun sawit berumur 7, 10 dan 14 tahun sebanyak 42 jenis yang bervariasi tiap umur tanaman sawit. Proporsi hijauan yang ada meliputi jenis rumput, legume dan paku-pakuan bervariasi pada tiap umur kebun sawit. Produksi hijauan yang ada di bawah kebun sawit berumur 7, 10 dan 14 tahun berturutturut $2.571 \mathrm{~kg} / \mathrm{ha}, 1.479,76 \mathrm{~kg} / \mathrm{ha}$ dan $1.417,22 \mathrm{~kg} / \mathrm{ha}$ dalam bentuk segar serta sebesar 811,41 $\mathrm{kg} / \mathrm{ha}, 471,15 \mathrm{~kg} / \mathrm{ha}$ dan $456,91 \mathrm{~kg} / \mathrm{ha}$ dalam bahan kering. Kapasitas tampung dari kebun sawit berumur 7, 10 dan 14 tahun adalah 0,36 satuan ternak (ST)/ha, 0,21 ST/ha dan 0,20 ST/ha.

\subsection{Tumbuhan Sebagai Pakan Alami Ternak Sapi Bali}

Hijauan makan ternak yang dipergunakan oleh ternak ruminansia sebagian besar rumputrumputan, sehingga rumput memegang peranan penting dalam penyediaan pakan dan telah umum digunakan oleh peternak dalam jumlah besar. Pemanfaatan limbah pertanian sebagai pakan alternatif adalah salah satu solusi untuk menanggulangi kekurangan pakan ternak ruminansia.Tumbuhan pakan alami pada lokasi penelitian dapat disajikan pada Tabel 2.

Tabel 2. Hijauan Pakan Ternak

\begin{tabular}{lll}
\hline No & \multicolumn{1}{c}{ Nama Lokal } & \multicolumn{1}{c}{ Nama Latin } \\
\hline 1. & Rumput-rumputan & Poaceae/Graminae \\
& a. Rumput Belulang & Elausine indica $(L)$ Gaertn \\
& b. Rumput Jakut Pahit & Axonopus compresus $(S W)$ P. Beauv \\
c. Rumput Malela & Braehiaria mutica $($ Forsk.) Stapf \\
d. Rumput Tembaga & Ischaemum muticum $(L)$ Raeusch \\
e. Rumput Telur Ikan & Cyrtococcum acerencens \\
f. Rumput Jari & Digitaria Cilliaris \\
g. Ischaemum & Ischaemum timorense kunth \\
h. Rumput Gajah & Pennisetum purpureum Schumach
\end{tabular}


i. Rumput Ilalang

\begin{tabular}{lll}
\hline 2. & Teki-tekian & Cyperaceae \\
\hline & a. Teki Ladang & Cyperus rotundus $L$. \\
& b. Udel Udelan & Cyperus kyllingia \\
\hline 3. & Kacang-kacangan & Leguminaceae \\
\hline & a. Alysicarpus & Alysicarpus vaginalis $(L) D C$. \\
b. Jakut Jeram & Dismodium triflorum $(L) D C$.
\end{tabular}

Sumber: Munadi, 2019

Tabel 2 menunjukkan bahwa spesies tumbuhan yang mendominasi adalah jenis rumput-rumputan, teki-tekian dan kacang kacangan. Hal ini didukung oleh kondisi alam yang memungkinkan jenis tanaman tersebut tumbuh dengan baik diarea perkebunan kelapa sawit. Pertumbuhan gulma atau pakan alami yang terdapat pada perkebunan kelapa sawit bervariasi tergantung pada umur dan jenis tanaman kelapa sawit itu sendiri bahwa beberapa dominasi pakan alami untuk ternak yang bisa dijadikan sebagai pakan ternak. Hijauan merupakan sumber pakan utama bagi ternak ruminansia sehingga berbagai upaya peningkatan produksi ternak dalam rangka memenuhi kebutuhan sumber protein hewani akan sangat sulit dicapai apabila ketersediaan hijauan pakan tidak sebanding dengan kebutuhan ternak yang ada. Produksi hijauan pakan dari waktu ke waktu semakin menurun seiring dengan beralihnya fungsi lahan untuk pemukiman, jalan, industri serta produksi tanaman pangan dan perkebunan, sementara produksi hijauan pakan sebagian besar dilakukan pada lahan lahan marjinal. Pemanfaatan ikutan perkebunan yang semula dipandang cukup menjanjikan sebagai pengganti hijauan unggul ternyata sulit diaplikasikan di lapangan karena rendahnya kandungan gizi dan tingginya faktor pembatas yang mengakibatkan rendahnya kecernaan.

\subsection{Summed Dominance Ratio (SDR)}

Perhitungan yang digunakan untuk menganalisis vegetasi gulma yang tumbuh dominan menggunakan summed dominance ratio (SDR) yang dapat menggambarkan dominansi gulma pada suatu areal tertentu dalam menguasai sarana tumbuh yang didapatkan dari besaran Kerapatan Mutlak (KM), Frekuensi Mutlak (FM), Kerapatan Nisbi (KN), Frekuensi Nisbi (FN), dan Nilai Penting (NP). Kerapatan dihitung dengan satuan individu (Moenadir, 1993).

Nilai SDR menunjukan dominansi suatu gulma yang tumbuh di perkebunan kelapa sawit. Jika nilai SDR suatu gulma tinggi, maka dominansi gulma tersebut tinggi. Begitupun sebaliknya, jika nilai SDR suatu gulma rendah, maka dominansinya rendah. Jenis tumbuhan di bawah tanaman kelapa sawit antara lain rumput-rumputan, tumbuhan berdaun sempit, tumbuhan berdaun lebar yang dikelompokkan dalam gulma. Namun, ada juga tumbuhan leguminosa, tumbuhan ini walaupun tumbuh liar tapi bermanfaat untuk tanaman pokoknya karena mempunyai kemampuan mendapatkan senyawa nitrogen untuk hidupnya, bahkan dapat berkontribusi nitrogen untuk lingkungan maupun tanaman pokoknya. Jenis leguminosa ini juga dibudidayakan di bawah tanaman kelapa sawit saat tanaman masih muda dan berfungsi sebagai penutup tanah. Summed Dominance Ratio (SDR) pada perkebunan kelapa sawit disajikan pada Tabel 3.

Tabel 3. Summed Dominance Ratio (SDR) Perkebunan Kelapa Sawit

\begin{tabular}{lccc}
\hline Bahasa Latin & Tanggetada & Watubangga & Polinggona \\
\cline { 1 - 3 } Jenis Gulma Perkebunan Sawit & SDR $(\%)$ & SDR $(\%)$ & SDR $(\%)$ \\
\cline { 1 - 4 } Poaceae/Graminae & 8.49 & 2.97 & 4.78 \\
\cline { 1 - 3 } Eleusine Indica (L.) Gaertn & 4.04 & 13.59 & 11.96
\end{tabular}




\begin{tabular}{|c|c|c|c|}
\hline Bahasa Latin & Tanggetada & Watubangga & Polinggona \\
\hline Jenis Gulma Perkebunan Sawit & SDR (\%) & $\operatorname{SDR}(\%)$ & $\operatorname{SDR}(\%)$ \\
\hline Brachiaria Mutica (Forsk.) Stapf & 2.88 & 1.69 & 1.19 \\
\hline Imperata Cylindrical & 3.11 & 2.33 & 0.79 \\
\hline Ischaemum Muticum (L.) & 2.18 & 1.69 & 2.79 \\
\hline Cyrtococcum Accrencens & 3.89 & 6.16 & 5.98 \\
\hline Digitaria Cilliaris & 4.90 & 1.69 & 11.16 \\
\hline Ischaemum Timorense Kunth & 2.10 & 5.09 & 5.58 \\
\hline Pennisetum Purpureum & 0.62 & 0.42 & 0.39 \\
\hline Cyperaceae/Teki Tekian & SDR (\%) & SDR (\%) & SDR (\%) \\
\hline Cyperus Rotundus L. & 2.49 & 2.97 & 0.39 \\
\hline Scleria Sumatrensis & 1.47 & 1.27 & 1.99 \\
\hline Cyperus Distans & 0.23 & 3.61 & 1.99 \\
\hline Cyperus Kylingia & 2.49 & 2.76 & 5.98 \\
\hline Polypodiaceae & SDR $(\%)$ & SDR (\%) & SDR (\%) \\
\hline Davilia Denticulata & 0.85 & 0.21 & 0 \\
\hline Rubiaceae & SDR (\%) & SDR (\%) & SDR (\%) \\
\hline Borreria Latifolia (Aubl.) K.Schum & 2.10 & 3.18 & 1.99 \\
\hline Verbenaceae & SDR (\%) & SDR (\%) & SDR (\%) \\
\hline Stachytarpheta Indica Vahl & 1.24 & 0 & 2.39 \\
\hline Aspleniaceae & SDR (\%) & SDR $(\%)$ & SDR $(\%)$ \\
\hline $\begin{array}{l}\text { Asplenium Platyneuron } \\
\text { Asteraceae }\end{array}$ & 0.15 & 2.76 & 0.39 \\
\hline Ageratum Conyzoides & 1.47 & 2.54 & 0.39 \\
\hline Chromolaena Odorata. $L$ & 1.71 & 0.63 & 0.39 \\
\hline Clidemia Hirta $(L)$ D. Don & 1.79 & 1.06 & 2.39 \\
\hline Mimosaceae & SDR (\%) & SDR (\%) & SDR (\%) \\
\hline Mimosa Pudica Linn & 1.86 & 0.84 & 2.79 \\
\hline Leguminaceae & SDR (\%) & SDR (\%) & SDR (\%) \\
\hline Calopogonium Mucunoides & 4.90 & 0.63 & 1.99 \\
\hline Alysicarpus Vaginalis (L.) DC & 4.90 & 5.73 & 5.18 \\
\hline Desmodium Triflorum (L.) DC & 2.95 & 2.12 & 3.19 \\
\hline Total SDR & 62.92 & 66.07 & 76.17 \\
\hline
\end{tabular}

Sumber : Munadi, 2019

Berdasarkan data Tabel 3 menunjukkan bahwa dominasi gulma pada perkebunan kelapa sawit yang berada di perkebunan kelapa sawit menunjukkan Summed Dominance Ratio (SDR) yang berbeda seperti Kecamatan Tanggetada memiliki nilai SDR sebanyak $62.92 \%$, Kecamatan Watubangga dengan nilai SDR sebanyak $66.07 \%$ dan Kecamatan Polinggona dengan nilai SDR sebanyak $76.17 \%$. Hal ini berbeda dengan penelitian Firison et al., (2019) bahwa 53 jenis tumbuhan bawah pada seluruh tegakan kelapa sawit yang terdiri atas 46 genus dan 29 famili. Begitupun penelitian yang dilakukan oleh Dahlianah, (2019) bahwa komposisi gulma pada perkebunan kelapa sawit belum menghasilkan (TBM) ditemui 5 Famili, 12 spesies dan 709 individu., dan Gulma kelapa sawit yang menghasilkan (TM) ditemukan 4 famili, 9 spesies, dan 537 individu. Struktur gulma yang dominan pada perkebunan kelapa sawit belum menghasilkan (TBM) adalah Panicum repen, dan Eleusine indica dengan nilai INP: 23,43, dan Tanaman kelapa sawit menghasilkan adalah Mikania micrantha, dengan Nilai INP: 31,57, dan Indeks keanekaragamannya jenis gulma pada kelapa sawit belum menghasilkan (TBM) 2,14, dan indeks keanekaragaman jenis gulma pada 
tanaman menghasilkan adalah 2,07. Tingkat keanekaragaman jenis gulma TBM dan TM dikategorikan sedang.

Indeks nilai penting setiap perkebunan berbeda-beda seperti penelitian yang dilakukan oleh Rostini et al., (2020) bahwa terdapat sepuluh jenis tanaman di area integrasi dan non integrasi sapi sawit. Paspalum conjugatum memiliki frekuensi relatif, kerapatan relatif dan Indeks Nilai Penting (INP) tertinggi dibanding hijauan pakan lainnya baik di area integrasi maupun non integrasi Hasil penelitian menunjukkan bahwa vegetasi hijauan pakan ternak diarea integrasi sapi sawit menunjukkan hasil yang lebih tinggi. Begitupun penelitian yang dilakukan oleh Pagala et al., (2019) bahwa terdapat 24 spesies dengan 9 famili, antara lain Graminae, Cyperaceae, Polypodiceae, Rubiaceae, Verbenaceae, Aspleniaceae, Asteraceae, Mimosaceae, dan Leguminaceae.

\subsection{Strategi Pengembangan Hijauan Makanan Ternak di Perkebunan Sawit}

Upaya pengembangan hijauan makanan ternak tidak terlepas dari berbagai permasalah baik yang bersifat strategis maupun manajerial dan tekhnis. Dalam hal ini strategis yang dimaksud adalah berkaitan dengan aspek-aspek yang diperlukan untuk menjawab peningkatan hijauan makanan ternak serta peran maupun fungsi yang menjawab segala tantangan yang akan dihadapi dalam pengembangan hijauan kedepan. Sedangkan manajerial menyangkut tentang sistem pengelolaan dan manajemen suatu kegiatan pengembangan sektor HMT untuk menghasilkan sistem pengelolaan dan manajemen yang sesuai dengan kaidah pengembangan HMT yang lebih baik. Dalam perkembangannya untuk mendukung strategi dan manajerial tidak terlepas dari faktor teknis untuk menunjang penyediaan sarana dan prasarana kegiatan usaha pengembangan HMT.

Ketersediaan Hijauan Makanan Ternak (HMT) peternak pada umumnya hanya mengandalkan hijauan lokal dari vegetasi pastura alam baik rumput, legume maupun gulma yang tumbuh liar di bawah areal tanaman kelapa sawit dan sering dijumpai di lahan-lahan kebun atau di pinggir lahan tanaman pangan. Lahan di bawah tanaman kelapa sawit ditumbuhi hijauan vegetasi pastura alam baik rumput, legume maupun gulma yang tumbuh liar, walaupun daya hasil dan kualitas hijauan jenis ini rendah dan sebagian di antaranya kurang disenangi (low edible) bagi ternak sapi, tetapi karena kekurangan hijauan maka terpaksa peternak menggembalakan atau memberikan pakan hijauan jenis lokal tersebut.

Masalah rendahnya kuantitas dan kualitas pakan sapi penyebabnya adalah pendapatan peternak sapi yang relatif masih rendah sehingga tidak mampu menyediakan dan membeli pakan bermutu tinggi. Keterbatasan sumber pakan hijauan untuk sapi juga dapat mengakibatkan berkurangnya kemampuan peternak untuk berusaha dalam skala ekonomi yang lebih efisien. Prawiradiputra dan Priyanti (2009) menyatakan bahwa hampir di seluruh wilayah produksi sapi, peternak rakyat mengalami masalah penyediaan dan pengadaan sumber hijauan pakan yang efektif dan tersedia sepanjang tahun.

Salah satu cara yang dapat ditempuh dalam rangka penyediaan pakan hijauan adalah introduksi tanaman hijauan unggul seperti rumput gajah (Pennisetum purpureum) di lahan di bawah pohon kelapa dalam sistem integrasi sapi dan kelapa (Salendu dan Elly, 2012). Sumarsono (2006) menjelaskan bahwa dengan penanaman hijauan di lahan kelapa dan penggunaan pupuk kompos pada tanaman kelapa dan hijauan dapat menghemat biaya pemupukan, dengan meniadakan pupuk kimiawi sehingga meningkatkan produk tanaman hijauan mapun kelapa yang cukup produktif. Polakitan (2012) melaporkan bahwa integrasi tanaman dan ternak di areal kelapa dapat meningkatkan produksi buah kelapa hampir dua kali lipat jumlahnya, melalui pemanfaatan limbah lumpur kotoran ternak (bioslurry) sebagai pupuk organik. Usaha budidaya ternak sapi potong, masih mengalami tantangan utama yaitu kurangnya atau kelangkaan ketersediaan pakan hijauan makanan ternak (HMT). Dengan demikian perlu upaya peningkatan pengetahuan keterampilan serta strategi melalui 
penyuluhan, pelatihan dan introduksi tanaman hijauan makanan ternak unggul untuk dibudidayakan dan dimanfaatkan bagi usaha ternak sapi potong.

Peternak umumnya hanya mengandalkan hijauan lokal dari vegetasi pastura alam baik rumput, legume maupun gulma yang menurut Paat dan Taulu (2012) dan Osak et al., (2018) bahwa umumnya peternak hanya memberi pakan hijauan untuk sapi dengan menggembalakan di lapangan, lahan pertanian dan tepi saluran irigasi. Padahal di daerah sentra kelapa terdapat lahan yang umumnya hanya monokultur tanaman kelapa yang dapat diintercropping dengan hijauan makanan ternak (HMT). Lahan hijauan milik peternak sangat terbatas dan juga dengan kualitas hijauan yang tersedia belum menggunakan bibit hijauan unggul, sehingga produktivitas hijauan pun sangat rendah. Padahal peternak sapi di Desa Blongko umumnya memiliki lahan kelapa yang dapat ditanami tanaman hijauan makanan ternak baik rumput maupun legume. Luas lahan kelapa jika ditanami rumput unggul kultivar rumput gajah (Pennisetum purpureum) yang diberikan pupuk kompos kotoran ternak akan mampu meningkatkan carrying capasity lahan penggembalaan sampai melebihi 30 ekor per ha (Paat dan Taulu, 2012).

Pemanfaatan lahan di bawah kelapa untuk hijauan juga berfungsi sebagai cover crop atau tanaman penutup tanah merupakan suatu tindakan konservasi pada saat bukan musim tanam. Apabila lahan di bawah pohon kelapa dimanfaatkan dengan menanam rumput yang berkualitas maka pendapatan yang diperoleh akan lebih tinggi (Salendu, 2012 dan Salendu et al., 2018). Aplikasi tanaman hijauan rumput Pennisetum purpureum di lahan kelapa sawit, jika tidak dilakukan pengolahan lahan yang baik akan terjadi persaingan penyerapan zat hara di lahan yang sama, sehingga perlu tambahan pupuk. Salah satu pupuk yang murah, mudah didapat dan ramah lingkungan yaitu pupuk kompos berbasis kotoran sapi.

Introduksi rumput hijauan makanan ternak (HMT) di lahan tanaman kelapa dapat menyebabkan kompetisi penyerapan zat hara tanah antara tanaman hijauan dan kelapa, sehingga perlu intensifikasi penggunaan pupuk untuk memenuhi kebutuhan kedua jenis tanaman tersebut. Pupuk yang digunakan pada lahan kelapa bisa pupuk kimia (in organic fertilizer), pupuk organik (organic fertilizer) ataupun kombinasi keduanya (Mantiquilla et al., 1994). Penanaman hijauan di lahan kelapa dan penggunaan pupuk kompos pada tanaman kelapa dan hijauan dapat menghemat biaya pemupukan, dengan meniadakan pupuk kimiawi sehingga meningkatkan produk tanaman hijauan maupun kelapa yang cukup produktif (Sumarsono, 2006 dan Salendu et al., 2018). Untuk itu, melalui program kemitraan masyarakat terhadap peternak ini dilakukan pelatihan pembuatan pupuk kompos

Penggunaan input pupuk kandang sebesar $10 \%$ menurut Suwandi (2005) dengan asumsi variabel lain konstan (ceteris paribus) dapat meningkatkan produksi sebesar 1,25\%. Lebih lanjut dinyatakan bahwa pemberian pupuk kandang dapat meningkatkan dan mempertahankan keanekaragaman dan kehidupan organisme tanah. Indikasinya bahwa pupuk kandang sangat dibutuhkan dalam meningkatkan kesuburan tanah. Menurut Kariyasa dan Pasandaran (2004), penggunaan pupuk anorganik secara terus menerus dan cenderung berlebih dapat menyebabkan banyak lahan pertanian di Indonesia berada pada kondisi sakit. Berdasarkan kondisi ini maka pupuk kandang sebagai pupuk organik mulai dilirik untuk mengsubstitusi pupuk anorganik. Kotoran sapi merupakan sumber hara yang dapat memperbaiki struktur tanah sehingga menjadi lebih gembur dan subur. Prasetyo dan Suriadikarta (2006) menyatakan bahwa pemberian bahan organik dari pupuk kandang dan sisa tanaman dapat memperbaiki sifat fisik tanah.

Selanjutnya, sebagai percobaan dalam strategi pengolahan hijaun pada perkebunan kelapa sawit ditanami Pennisetum purpureum dengan jarak tanam 100x50 cm maka jumlah rumpun potensial sebanyak 20.000 rumpun per hektar, sedangkan pupuk kompos berbasis kotoran sapi digunakan sebanyak 10 ton basah. Lahan kelapa sawit yang digunakan seluas 0.5 hektar, sehingga jumlah benih yang digunakan sebanyak 10.000 batang (stek) dan pupuk 
kompos sebanyak 5 ton basah. Hasil produksi rumput Pennisetum purpureum di lahan kelapa sawit yang diberi pupuk kompos berbasis kotoran sapi dengan jarak tanam 100 x $50 \mathrm{~cm}$ atau 20.000 rumpun tanaman per ha dikurang 20 persen lahan tidak efektif ditumbuhi tanaman hijauan karena tegakan pohon kelapa sawit, maka jumlah tanaman hijauan sebanyak 16.000 rumpun yang memiliki potensi hasil hijauan segar sebanyak $79,752.73 \mathrm{~kg}$ setiap panen. Setelah panen pada panen pertama pada 75 HST (hari setelah tanam) dengan jarak panen sampai 45 hari, maka dalam setahun terdapat 8,3 kali panen, sehingga hasil pakan hijauan segar per tahun adalah $661,947.64 \mathrm{~kg}$ per hektar per tahun. Jumlah konsumsi per ekor sapi dewasa per hari sebanyak $40 \mathrm{~kg}$ segar, maka stocking rate atau tingkat ketersediaan pakan rumput Pennisetum purpureum per ha lahan di bawah kelapa sawit dapat diberikan bagi sejumlah 45,34 ekor ternak sapi dewasa dalam setahun.

\section{BAB III SARAN DAN REKOMENDASI}

Menurut penulis saran serta rekomendasi untuk pengembangan Hijauan Makanan Ternak pada lahan perkebunan kelapa sawit adalah sebagai berikut.

1. Kemampuan penyediaan pakan hijauan makan ternak (HMT) untuk sapi masih rendah karena produktivitas lahan penggembalaan yang tidak efektif dan produktivitas tanaman hijauan makanan ternak vegetasi alam yang rendah produksinya. Oleh sebab itu, strategi yang dapat diterapkan adalah teknologi introduksi bibit tanaman hijauan unggul seperti jenis hijauan kultivar rumput gajah (Pennisetum purpureum).

2. Adanya lahan tanaman kelapa sawit yang tidak dimanfaatkan baik untuk tanaman tumpangsari ataupun mix farming seperti tanaman pangan ataupun tanaman pakan hijauan makanan ternak. Oleh sebab itu, strategi yang dapat dilakukan adalah dengan memanfaatkan lahan di bawah tanaman kelapa untuk budidaya tanaman hijauan makanan ternak (HMT).

3. Pemanfaatan lahan untuk budidaya tanaman HMT di bawah tanaman kelapa sawit dapat menyebabkan produktivitas hijauan maupun buah kelapa sawit akan makin berkurang, karena dapat terjadi persaingan pemanfaatan zat hara tanah antara tanaman HMT dengan tanaman kelapa sawit. Oleh sebab itu, strategi yang dapat diterapkan adalah teknologi pupuk kompos berbahan baku kotoran ternak sapi dan limbah tanaman, untuk meningkatkan produktivitas baik produksi hijauan maupun produksi buah kelapa sawit.

4. Perlunya penerapan model sistem integrasi sapi dengan kelapa (SISKA) yang bermuara pada peningkatan produktivitas ekonomi yaitu pendapatan sistem usahatani terpadu ternak sapi dan tanaman kelapa sawit.

\section{DAFTAR PUSTAKA}

Afrianti, I., Yolanda, R., dan Purnama, A. A. (2014). Analisis Vegetasi Gulma Pada Perkebunan Kelapa Sawit (Elaeis Quinensis Jacq.) Di Desa Suka Maju Kecamatan Rambah Kabupaten Rokan Hulu, Perbal: Jurnal Pertanian 6(1), 1-6.

Dahlianah, I. (2019). Keanekaragaman Jenis Gulma Di Perkebunan Kelapa Sawit Desa Manggaraya Kecamatan Tanjung Lago Kabupaten Banyuasin. Indobiosains, 1(1), 30-47. https://doi.org/10.31851/indobiosains.v1i1.2296

Firison, J., Wiryono, W., dan Brata, B. (2019). Keragaman Jenis Tumbuhan Bawah Pada Tegakan Kelapa Sawit Dan Potensinya Sebagai Pakan Ternak Sapi Potong (Kasus

Di Desa Kungkai Baru Kabupaten Seluma). Naturalis: Jurnal Penelitian Pengelolaan Sumber Daya Alam dan Lingkungan, 8(1), 67-76. 
Gopar, R. A., Martono, S., Rofiq, M. N., dan N, W. (2015). Potensi Covercrop Kebun Sawit Sebagai Sumber Pakan Hijauan Ternak Ruminansia Pada Musim Kemarau di Pelalawan, Riau. Jurnal Sains Dan Teknologi Indonesia, 17(1), 24-31.

Kocu, O., Salundik, S., Priyanto, R., dan Prihantoro, I. (2017). Produktivitas Sapi Bali di Lahan Pastura dan Perkebunan Kelapa Sawit di Kabupaten Keerom Provinsi Papua. Jurnal Ilmu Produksi dan Teknologi Hasil Peternakan, 5(3), 110-116.

Moenandir, J. (1993). Ilmu Gulma. Raja Grafindo Persada. 181 hal.

Munadi, L., M. (2019). Kajian Ketersediaan Pakan Ternak Sapi Bali Terintegrasi Perkebunan Kelapa Sawit Di Kabupaten Kolaka. Tesis. Pascasarjana Universitas Halu Oleo. Kendari.

Osak, R. E. M. F., T. F. D. Lumy, and M. L. Rundengan, (2018). Application of Environmentally Friendly Technology To Dairy Farming In South Tomohon Subdistrict, North Sulawesi, Indonesia. International Journal of Engineering Inventions 7(4):16-18.

Paat, P.C., Dan Taulu (2012). Prospek Integrasi Ternak Ruminansia Pada Perkebunan Kelapa Melalui Introduksi Hijauan Pakan Unggul Di Sulawesi Utara. Prosiding Seminar Nasional Peternakan. Medan, 19 Mei 2012. Hal. 65-72.

Pagala, M. A. Munadi, L., M. dan Zulkarnain, D. (2019). Diversity And Green Types Carrying Capacity Bali Beef In Oil Palm Plantation In Kolaka District. Indonesian Journal of Animal Agricultural Science, 1(1), 48-55.

Prawiradiputra, B. R., dan A. Priyanti, (2009). Teknologi Pasokan Hijauan Pakan Yang Berkelanjutan Mendukung Pengembanganusaha Sapi Perah di Indonesia. Prosiding Semiloka Nasional Prospek Industri Sapi Perah Menuju Perdagangan Bebas 2020. Hal.107-114.

Rostini, T., Djaya, S., dan Adawiyah, R. (2020). Analisis Vegetasi Hijauan Pakan Ternak di Area Integrasi dan Non Integrasi Sapi dan Sawit. Jurnal Sain Peternakan Indonesia, 15(2), 155-161.

Saleh, A., Dibisono, M. Y., dan Gea, S. U. (2020). Keragaman Gulma Pada Tanaman Kelapa Sawit (Elaies guineensis Jacq.) Belum Menghasilkan Dan Sudah Menghasilkan Di Kebun Rambutan PT. Perkebunan Nusantara III. Jurnal Agro Estate, 4(1), 1-11. https://doi.org/10.47199/jae.v4i1.131.

Salendu, A.H.S. dan F.H. Elly, (2012). Pemanfaatan Lahan Di Bawah Pohon Kelapa Untuk Hijauan Pakan Sapi Di Sulawesi Utara. Pastura 2(1):21-25.

Salendu, A. H. S., F. H. Elly, R. E. M. F. Osak and I. D. R. Lumenta, (2018). Cattle Farm Development by Forages Cultivation on Coconut Land Based on Carrying Capacity in West Bolangitang, Indonesia. International Journal of Environment, Agriculture and Biotechnology (IJEAB) 3(3):1139-1144.

Sumarsono, (2006). Peran Tanaman Pakan Dalam Intervensi Pertanian Berwawasan Lingkungan. Makalah Utama dalam Silaturahmi Ilmiah Fakultas Peternakan Universitas Diponegoro Semarang, 29 Maret 2006.

Suryana, Chozin, M. A., dan Guntoro, D. (2019). Identifikasi Spesies Tanaman Penutup Tanah pada Perkebunan Kelapa Sawit Menghasilkan. Jurnal Agronomi Indonesia (Indonesian Journal of Agronomy), 47(3), 305-311.

Trisna, T., Wiryono, W., dan Apriyanto, E. (2018). Tumbuhan Bawah Pada Perkebunan Kelapa Sawit Tua (TM) Dan Sawit Muda (Ti) Dengan Peremajaan Teknik Underplanting Di Pt. Bio Nusantara Teknologi. Naturalis: Jurnal Penelitian Pengelolaan Sumber Daya Alam Dan Lingkungan, 7(2), 61-70. 
